\title{
Why should a neuropaediatrician always measure head circumference - a case report of Glucose transporter 1 deficiency syndrome (Glut1-DS)
}

\author{
Dlaczego neurolog dziecięcy MUSI zawsze mierzyć obwód głowy - opis przypadku deficytu \\ transportera glukozy typu 1 (Glut1-DS)
}

\author{
Barbara Oleksy (D), Hanna Mierzewska (iD), Agata Lipiec (D), Elżbieta Szczepanik (D) \\ Clinic of Paediatric Neurology, Institute of Mother and Child, Warsaw \\ Klinika Neurologii Dzieci i Młodzieży, Instytut Matki i Dziecka, Warszawa \\ DOI:10.20966/chn.2020.58.464
}

\section{ABSTRACT}

Introduction. The deficit of the type 1 glucose transporter (Glut1-DS) belongs to the neurometabolic disorders that can be effectively treated, in this case with ketogenic diet. By limiting glucose supply to the brain the deficit of glucose transporter 1 leads to cerebral energy deficiency. Glut1-DS manifests with a wide range of neurological symptoms that usually start in early childhood, including cognitive impairment, epilepsy and permanent and/or paroxysmal motor disorders, often provoked by physical activity, fasting or hyperthermale.

Aim. We present the case of a 6,5-year-old patient with Glut1-DS who, despite presenting typical symptoms, remained undiagnosed for years. Family history was positive of intellectual disability in first degree relative. The child suffered from psychomotor development delay, motor coordination difficulties, motor disorders and epilepsy with focal and absence seizures of early onset. However, the significant symptom of secondary microcephaly remained unnoticed for years.

Conclusion. Secondary microcephaly is a valuable symptom which can guide towards the diagnosis. The early diagnosis of Glut1 deficiency syndrome enables prompt introduction of the ketogenic diet crucial for the child's development and improvement of both the patients and their families' quality of life.

Key words: Glut1-DS, glucose transporter 1 deficiency syndrome, head circumference, epilepsy.

\section{STRESZCZENIE}

Wstęp. Deficyt transportera glukozy typu 1 (Glut1-DS.) należy do tych nielicznych neurometabolicznych schorzeń, które mogą być skutecznie leczone, w tym wypadku dietą ketogenną. Deficyt transportera 1, poprzez redukcję transportu glukozy do OUN, prowadzi do deficytu energetycznego mózgu. Schorzenie to charakteryzuje się wieloma objawami ze strony układu nerwowego, najczęściej z początkiem w okresie wczesnego dzieciństwa. Należą do nich zaburzenia poznawcze, padaczka, dysfunkcje ruchowe o przewlekłym charakterze lub występujące napadowo, często prowokowane wysiłkiem, głodzeniem czy zwyżką ciepłoty ciała.

Cel. Celem pracy było przedstawienie przypadku 6,5 letniej pacjentki z Glut1-DS, u której rozpoznanie było opóźnione pomimo obecności typowych dla tego schorzenia objawów klinicznych. Wywiad rodzinny był obciążony występowaniem niepełnosprawności intelektualnej u krewnego I stopnia. U dziecka obserwowano nieprawidłowy rozwój poznawczy, niezgrabność ruchową oraz padaczkę z napadami ogniskowymi oraz nieświadomości o wczesnym początku. Jednakże, istotny objaw diagnostyczny, jakim było małogłowie wtórne, długo nie był rejestrowany.

Wnioski. Małogłowie wtórne jest istotnym objawem ukierunkowującym diagnostykę. Wczesne rozpoznanie Glut1-DS. umożliwia wprowadzenie skutecznego leczenia dietą ketogenną, co prowadzi do poprawy rozwoju dziecka i tym samym do polepszenia jakości życia pacjenta i jego rodziny.

\section{Stowa kluczowe:}

Glut1-DS, deficyt transportera glukozy typu 1, obwód głowy, padaczka.

\section{INTRODUCTION}

The deficit of the type 1 glucose transporter (OMIM \#606777) was first described by De Vivo et al in 1991 [1]. The disease is caused most often by dominant mutation in SLC2A1 gene on chromosome 1 (OMIM *138140) [2]. A very severe recessive biallelic form is extremely rare. Glut1-DS is an infrequent, but increasingly recognized, disorder of glucose transport through the blood-brain barrier and the astrocyte cell membrane, resulting in an insufficient supply of glucose to the brain. Glut1-DS manifests with a wide range of neurological symptoms that usually start in early childhood, including cognitive impairment, epilepsy, and permanent and/or paroxysmal motor disor- ders such as dystonia, ataxia, often provoked by physical activity, fasting and hypertermia $[3,4]$. There are two main types of the disease. The severe "classic" type often starts at the age of 4-6 months as developmental encephalopathy with epilepsy with different types of seizures, a variety of epileptic syndromes and secondary microcephaly due to deceleration of head growth. Both epilepsy with absences of early onset and epilepsy with myoclonic atonic seizures are epileptic syndromes quite typical for the clinical spectrum of Glut1-DS. [3-6]. The milder variant of Glut1 deficiency syndrome may start later on during lifetime. The intermediate phenotypes are also encountered [5, 7]. Patients with Glut1-DS often show daily fluctuation of the 
symptoms depending on the time of meals. The symptoms increase during fasting and, vice versa, decrease after meals rich in simple carbohydrates [3].

The diagnosis is made based on the characteristic clinical picture, low glucose concentration in the cerebrospinal fluid (CSF), low glucose $\mathrm{CSF} /$ serum ratio and the genetic test confirming the pathogenic mutation in the SLC2A1 gene $[3,4]$. It is worth mentioning that originally the level of glucose in CSF below $40 \mathrm{mg} / \mathrm{dL}$ and glucose index below 0.45 were a prerequisite for the diagnosis $[1,3]$. On the basis of subsequent experiences with diagnosed patients, it turned out that there are also milder phenotypes with both higher glucose level in the CSF and glucose index, but still below the norm range [1]. Lumbar puncture should always be performed after a fasting period of at least 4 hours or after a night sleep.

Although a correct and not delayed diagnosis of Glut1-DS helps managing seizures and improves a child's development, an insufficient recognition of phenotypes still contributes to the underdiagnosis of this disorder.

Hereby, we present the case of a 6,5-year-old girl with Glut1-DS in order to analyze the reasons why, despite showing the classic symptoms, the patient remained undiagnosed for years.

\section{CASE REPORT}

The female patient was born by spontaneous vaginal delivery at 40 weeks of gestation after an uneventful III pregnancy, with a body weight of $3100 \mathrm{~g}$, length $53 \mathrm{~cm}$, head circumference of $34 \mathrm{~cm}$ (25-50 pct.) She was assessed with 10 points of the Apgar scale. The family history was positive for intellectual disability, possibly epilepsy, in the biological mother.

Delay in psychomotor development has been observed since the infancy especially in terms of unsteady and clumsy gait, impaired fine motor skills and speech. Single words appeared at the age of 2-3 years, full sentences not earlier than at the age of 4 years. The speech was dysarthric at that time. The girl underwent systematic rehabilitation and stimulation of the development. The first epileptic seizure was observed before 2-nd year of age. It was an unaware focal seizure with upward eyes deviation, lasting a few seconds. Later on, except from focal onset seizures, the absences occurred with noticeable predominance in the mornings before breakfast. In addition, after physical effort the parents observed the episodes of gait disturbances accompanied by pain and tremor in the lower limbs. The girl has been under neurological care since the age of 2 years. She was repeatedly hospitalized in several centers where epilepsy and development delay were diagnosed. However, in numerous medical records the measurement of patient's head circumferences was not included. In electroencephalographic (EEG) studies, the bursts of generalized spike-wave complexes with predominance in the anterior regions were recorded. Most metabolic diseases were excluded, except for Glut1-DS. MRI of the brain showed no significant changes that could explain the background of the disorders presented by the patient. Treatment with valproic acid, ethosuxi- mide, levetiracetam, lacosamide and topiramate was performed in various configurations, with no improvement. At the age of 6 years and 8 months the child was admitted to the Clinic of Paediatric Neurology of the Mother and Child Institute. The physical examination revealed secondary microcephaly (head circumference was $48.7 \mathrm{~cm}$ ( $<3$ rd percentile/-2 SD) and features of motor coordination difficulties. A neuropsychological assessment revealed mild intellectual disability, attention deficit, high level of cognitive fatigue and difficulties in memory functions. In addition, speech disorders and reduced manual dexterity, including graphomotor skills, were observed. In the interictal EEG traces performed during wakefulness and sleep, bursts of generalized spike and wave complexes $3-3.5 \mathrm{~Hz}$ were recorded. Based on the medical history and clinical picture with i.a. absence seizures of early onset and secondary microcephaly, the deficit of the glucose transporter type 1 was suspected. Lumbar puncture was performed in order to determine the level of glucose and lactic acid in the cerebrospinal fluid. The patient's fasting glucose concen-tration in serum was $90 \mathrm{mg} / \mathrm{dL}$ and glucose concentration in the cerebrospinal fluid was $39.5 \mathrm{mg} / \mathrm{dL}$, so the glucose $\mathrm{CSF} /$ serum index was 0.44 . Lactic acid concentration was within normal range. Based on the results mentioned above and the clinical picture, the Glut1-DS was diagnosed, which was finally confirmed by genetic testing. A pathogenic mutation [c.410C > T]; [p.Thr137lle] in the SLC2A1 gene has been detected. Treatment with ketogenic diet was introduced.

\section{DISCUSSION}

Glut1 deficiency syndrome is a disorder that results in cerebral energy deficiency[1, 3,4$]$. This disorder belongs to a few treatable neurometabolic disorders, therefore an early detection of Glut1-DS is essential for prompt introduction of ketogenic diet, which enables normal neurodevelopment and can improve patient's life. Establishing the diagnosis of Glut1-DS can sometimes be challenging due to the variability of the clinical picture, the age of onset and phenotypic evolution over time [7]. However, our patient with intellectual disability presented with number of symptoms characteristic for Glut1-DS. In family history there was an intellectual disability in first degree relative, what could have pointed to genetic background of the disease. In addition the girl was born with normal head circumference, while secondary microcephaly was first diagnosed at the age of nearly 7 years. Moreover, she suffered from atypical epilepsy with absences of early onset, in addition to focal seizures. Most seizures were occurring in the mornings before her first meal, what could have suggested a relation to long night fasting. Additionally, repeated post-exertion gait disturbance was a very suggestive symptom of energy deficiency syndrome.

In this paper, the authors focused on the problem of secondary microcephaly. The deceleration of the growth of head circumference is a nonspecific phenomenon which is observed in many metabolic and neurodegenerative diseases. Regretfully, this very important measurement is often 
disregarded. Our experience demonstrates that the growth curve of the head circumfer-ence is not always analyzed, and the measurement of the head circumference at birth is repeatedly missing in neurological epicrises. Furthermore, the information on microcephaly, when provided, does not state its primary or secondary character. This data is essential for comprehensive analysis of the case and often guides the medical examination towards the final diagnosis.

Secondary microcephaly is present in many patients suffering from Glut1 deficiency syndrome and correlates to the severity of the glucose transporter 1 deficit [1]. In case of detection of the inhibition of growth of head circumference in addition to suggestive clinical data, Glut1-DS should be considered. In our patient deceleration of head growth was neglected until she was admitted to our clinic. Therefore the importance of the head circumference measurement by paediatric neurologists should be emphasized. This easy test should constitute the part of every examination, as it can lead towards the right diagnosis and subsequently influence the patient healing process.

\section{REFERENCES:}

[1] De Vivo, D.C., Trifiletti, R.R., Jacobson, R.I., et al.: Defective glucose transport across the blood-brain barrier as a cause of persistent hypoglycorrhachia, seizures, and devel-opmental delay. New Eng. J. Med. 1991; 325: 703-709.

[2] OMIM, Online Mendelian Inheritance of Man, available: www.omim.org, February 2021.

[3] Klepper J., Akman C., Armeno M., et al.: Glut1 Deficiency Syndrome (Glut1DS): State of the art in 2020 and recommendations of the international Glut1DS study group. Epilep-sia Open 2020; 5: 354-365.

[4] Klepper J.: GLUT1 deficiency syndrome in clinical practice. Epilepsy Res. 2012; 100: 272-277.

[5] Koch H., Weber Y.G.: The glucose transporter type 1 (Glut1) syndromes. Epilepsy Behav. 2019; 91: 90-93.

[6] Szczepanik E., Terczyńska I., Kruk M., et al.: Glucose transporter type 1 deficiency due to SLC2A1 gene mutationsa rare but treatable cause of metabolic epilepsy and extrapyramidal movement disorder; own experience and literature review. Dev Period Med. 2015; 19: 454-463.

[7] Winczewska-Wiktor A., Hoffman-Zacharska D., Starczewska M., et al.: Variety of symptoms of GLUT1 deficiency syndrome in three-generation family. Epilepsy Behav. 2020; 106:107036. 